\title{
Improvement of a low pH antigen-antibody dissociation procedure for ELISA measurement of circulating anti-A $\beta$ antibodies Qingyou Li ${ }^{1}$, Marcia Gordon ${ }^{1}$, Chuanhai $\mathrm{CaO}^{2,3}$, Kenneth E Ugen ${ }^{2}$ and Dave Morgan*1
}

Address: ${ }^{1}$ Alzheimer's Research Laboratory, Department of Molecular Pharmacology and Physiology, University of South Florida, Tampa, FL 33612-4799, USA, 2Department of Molecular Medicine, University of South Florida, Tampa, FL 33612-4799, USA and ${ }^{3}$ Byrd Institute for Alzheimer's Disease, Tampa, FL 33612-4799, USA

Email: Qingyou Li - qli@hsc.usf.edu; Marcia Gordon - mgordon@hsc.usf.edu; Chuanhai Cao - ccao@byrdinstitute.org; Kenneth E Ugen - kugen@hsc.usf.edu; Dave Morgan* - dmorgan@hsc.usf.edu

* Corresponding author

Published: 20 March 2007

BMC Neuroscience 2007, 8:22 doi:10.1/86//47|-2202-8-22
Received: 3 November 2006

Accepted: 20 March 2007

This article is available from: http://www.biomedcentral.com/I47I-2202/8/22

(c) $2007 \mathrm{Li}$ et al; licensee BioMed Central Ltd.

This is an Open Access article distributed under the terms of the Creative Commons Attribution License (http://creativecommons.org/licenses/by/2.0), which permits unrestricted use, distribution, and reproduction in any medium, provided the original work is properly cited.

\begin{abstract}
Background: Prior work from our group found that acid dissociation ( $\mathrm{pH} 2.5$ incubation) of serum from APP transgenic mice vaccinated against $A \beta$ increased the apparent anti-A $\beta$ titers, suggesting antibody masking by antigen in the ELISA assay. Subsequently, we found that $\mathrm{pH} 2.5$ incubation of serum from unvaccinated nontransgenic mice showed antibody binding to $A \beta I-42$, but no increase when other proteins, including shorter $A \beta$ peptides, coated the ELISA plate. To investigate further the effects of low $\mathrm{pH}$ incubation on apparent anti-A $\beta \mathrm{I}-$ 42 signals, we examined normal sera from nonTg unvaccinated mice, nonTg mice vaccinated with $A \beta$ peptide (to produce authentic anti-A $\beta$ antibodies) or a monoclonal antibody against $A \beta$ (6E I0) using competitive-inhibition ELISA and $A \beta$ epitope mapping assays. In addition, we examined use of a less stringent low $\mathrm{pH}$ procedure at $\mathrm{pH}$ 3.5 , to ascertain if it had the same effects as the $\mathrm{pH} 2.5$ procedure.

Results: We believe there are three distinct effects of $\mathrm{pH} 2.5$ incubation.; A) an artifactual increase in binding to full length $A \beta$ by mouse immunoglobulin which has low affinity for $A \beta, B$ ) an inactivation of anti-A $\beta$ antibodies that is time dependent and $C$ ) unmasking of high affinity anti-A $\beta$ antibodies when high levels of circulating $A \beta$ is present in APP transgenic mice. All three reactions can interact to produce the final ELISA signal. Incubation of sera from unvaccinated nonTg mice at $\mathrm{pH} 2.5$ enhanced ELISA signals by process A. Conversely, $\mathrm{pH} 2.5$ incubation of sera from vaccinated nonTg mice with caused a time dependent reduction of antibody signal by process $B$ (overcoming the increase caused by $A$ ). The artifactual anti-A $\beta$ ELISA signal enhanced by $\mathrm{pH} 2.5$ incubation of normal mouse sera could not be effectively competed by low to moderate concentrations of $A \beta$, nor bind to shorter $A \beta$ peptides in a manner similar to authentic anti-A $\beta$ antibodies. Incubation of mouse sera at $\mathrm{pH} 3.5$ caused neither an apparent increase in anti-A $\beta$ ELISA signal, nor an inactivation of the ELISA signals resulting from either vaccination or monoclonal antibodies. However, incubation at $\mathrm{pH} 3.5$ was able to completely reverse the reduction in ELISA signal caused by $A \beta$ complexing with antibodies in sera from vaccinated mice or monoclonal anti-A $\beta$ antibodies.

Conclusion: Incubation at $\mathrm{pH} 3.5$ is sufficient to dissociate $\mathrm{A} \beta$ bound to anti-A $\beta$ antibodies without producing artifactual increases in the signal, or inactivating authentic antibody binding. Thus, use of $\mathrm{pH} 3.5$ is a considerable improvement over $\mathrm{pH} 2.5$ incubation for unmasking anti-A $\beta$ antibodies in ELISA assays to measure antibodies in APP transgenic mouse sera.
\end{abstract}




\section{Background}

It has been well documented that active immunization of transgenic mice against the $A \beta$ peptide can dramatically reduce the deposition of amyloid [1] and improve learning and memory behavior in amyloid depositing transgenic mice[2,3]. However, the anti- $A \beta$ antibody response to vaccination of amyloid precursor protein (APP) transgenic mice appeared lower than in nontransgenic (nonTg) littermates [4-6]. It has also been reported in some studies that patients with Alzheimer disease (AD) have lower levels of serum anti-A $\beta$ antibodies than healthy age-matched individuals $[7,8]$, although others report no change [9] or an increase [10].

This impaired antibody response may result from self tolerance in the APP transgenic mice, or absorption of the serum antibody by circulating $A \beta$, which interferes with antibody binding to $A \beta$ coated ELISA plates (these are not mutually exclusive). This latter explanation was supported by our prior work, where acid dissociation of serum increased the apparent anti- $\mathrm{A} \beta$ antibody titer in vaccinated APP transgenic mice [5]. Subsequently, we unexpectedly found that the $\mathrm{pH} 2.5$ dissociation procedure also enhanced ELISA signals against $\mathrm{A} \beta 1-42$ in normal sera from nonTg unvaccinated mice. This suggested that either a) normal mice have measurable anti- $\mathrm{A} \beta$ antibody titers that are masked by the low levels of circulating murine $\mathrm{A} \beta$ or $\mathrm{b}$ ) $\mathrm{pH} 2.5$ incubation produces nonspecific interactions between IgG and human A $\beta 1-42$.

We have performed over 100 experiments in the last 3 years in order to identify which of these options is correct. Our data now convince us A) pH 2.5 incubation does produce an artifactual association between IgG and full length $A \beta$ that is not due to typical antigen-antibody interactions. In addition, we find that $\mathrm{B}$ ) $\mathrm{pH} 2.5$ incubation also causes inactivation of authentic anti-A $\beta$ antibodies formed by vaccination. Finally, C) the low $\mathrm{pH}$ incubation can unmask antibody bound to $A \beta$ in circulation. Our prior data are now explained in terms of all three events occurring simultaneously. In addition, we demonstrate that use of pH 3.5 instead of $\mathrm{pH} 2.5$ can eliminate the artifactual binding and the antibody inactivation, while retaining the antibody-antigen dissociation required to assess the true antibody titers in serum.

\section{Results}

An increased anti-A $\beta$ ELISA signal in sera from vaccinated transgenic mice with preincubation at $\mathrm{pH} 2.5$ is also found in sera from nonTg unvaccinated mice

As observed previously, preincubation at $\mathrm{pH} 2.5$ increases the ELISA signal against $A \beta 1-42$ when sera are taken from APP transgenic mice that have been vaccinated against the $A \beta$ peptide (fig $1 \mathrm{~A}$ ). This enhanced signal was not observed when other proteins or PBS were used to coat the
ELISA plate. We had interpreted this as indicating that the low $\mathrm{pH}$ incubation dissociated antigen antibody complexes formed in the serum of vaccinated mice overproducing $A \beta$ (due to APP transgenesis). However, when we performed the same $\mathrm{pH} 2.5$ preincubation using normal sera from nonTg mice (thus not overproducing the $A \beta$ peptide) who had never been vaccinated against $A \beta$ (thus, presumed to have very low anti-A $\beta$ titers), we observed a similar, albeit smaller, increase in the apparent anti-A $\beta$ titer (fig. 1B; note difference in $\mathrm{Y}$ axis values). Moreover, this also was specific for $\mathrm{A} \beta 1-42$ relative to other proteins. This latter signal we now believe is due to the artifactual binding of mouse immunoglobulin to $A \beta 1-42$ after incubation at $\mathrm{pH} 2.5$ (process A).

\section{$\mathrm{pH} 2.5$ induced artifactual anti-A $\beta$ ELISA signal appears due to IgG rather than other serum proteins}

In our prior dissociation study, the detection (secondary) antibody was directed against whole-mouse IgG (Sigma, product \# A 4416). There is some potential for this detection antibody to react with other Ig classes such as IgM or IgA. To address whether the enhanced ELISA signal from nonTg unvaccinated mice after acid dissociation is specific for IgG, we tested a more specific anti-mouse IgG $\gamma$-chain detection antibody (Sigma, product\# A 3673). The data showed the ELISA signal detected by anti-mouse $\operatorname{IgG} \gamma$ chain antibody was the same as detected by anti-whole IgG antisera (fig. 2A). In addition, IgG purified from nonTg unvaccinated mice using ImmunoPure (protein A/ G) IgG purification Kit retained the enhanced signal towards $\mathrm{A} \beta$ on ELISA plates when incubated at $\mathrm{pH} 2.5$. (fig. 2B). These data indicate that artifactual $\mathrm{pH} 2.5$ induced anti-A $\beta$ ELISA signal appears associated with IgG.

\section{Duration of low $\mathrm{pH}$ exposure differentially affects anti-A $\beta$ ELISA signals in sera from unvaccinated mice compared to vaccinated mice}

The sera from unvaccinated nonTg mice and nonTg mice vaccinated against $A \beta$ were exposed to dissociation buffer $\mathrm{pH}$ at 2.5 for 5, 20, 30, 90 and 120 minutes. The data showed that the ELISA signal of unvaccinated mice (fig. $3 \mathrm{~A}$ ) increased in a time dependent manner when the sera were preincubated at $\mathrm{pH} 2.5$. However, in vaccinated mice which have authentic anti-A $\beta$ antibodies, the antiserum titers raised against human A $\beta 1-42$ peptide were decreased in a time dependent fashion (fig. 3B; also note the different $\mathrm{Y}$ axes between the two figures) Thus in the absence of authentic anti- $\mathrm{A} \beta$ antibody (3A), low $\mathrm{pH}$ artifact (process $\mathrm{A}$ ) is the only process active and increases the apparent anti-A $\mathrm{A}$ titer, while in the presence of authentic antibody (3B) the $\mathrm{pH} 2.5$ exposure inactivates antibody (process $\mathrm{B}$ ) and this overcomes any artifactual increase present in the sera. 
A

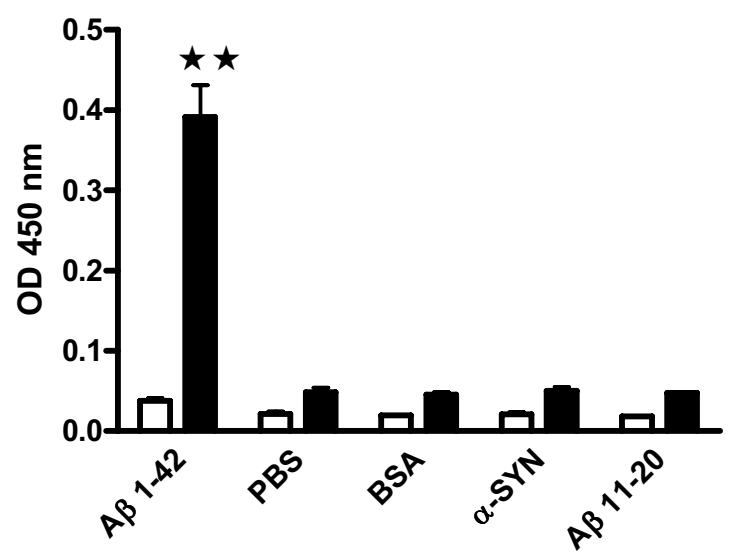

B

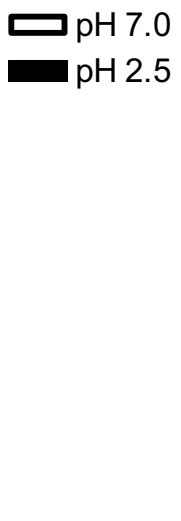

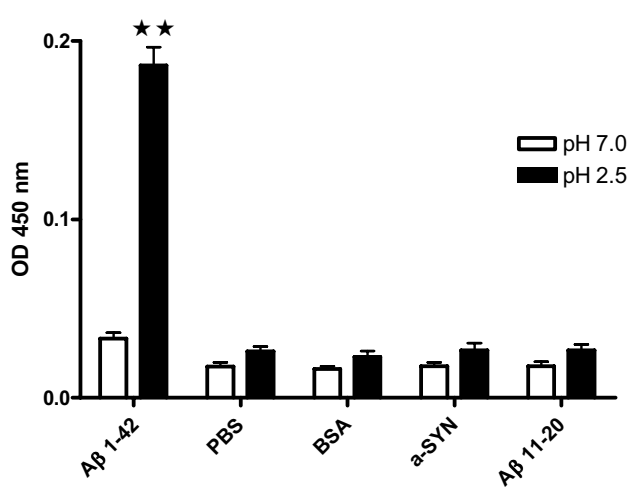

\section{Figure I}

Incubation at $\mathrm{pH} 2.5$ induced increase in anti-A $\beta$ ELISA signal is present not only in sera from vaccinated mice, but also untreated mice. Sera were collected from APP transgenic mice vaccinated $(\mathrm{Vax}+)$ with $A \beta I-42($ panel $A)$ and nonTg unvaccinated (Vax -) mice (panel B; normal serum), preincubated with dissociation buffer at either $\mathrm{pH} 7$ (open bars) or $\mathrm{pH} 2.5$ (solid bars) at room temperature for 20 minutes and centrifuged through 10,000 MW filters, brought to neutral pH and reconstituted to the original serum dilution volume. The sera were then incubated on ELISA plates coated with one of the following at $5 \mu \mathrm{g} / \mathrm{ml}$; human $A \beta I-42$, phosphate buffered saline (PBS; a "no protein" control), bovine serum albumin (BSA), recombinant alpha-synuclein (a-SYN) or A $\beta$ peptide amino acids I I-20. ELISA assays were completed as described in methods and the optical density (OD) at $450 \mathrm{~nm}$ used to estimate the amount of antibody binding to the ELISA plate. Note different $Y$-axis scales in panels $A$ and $B$. Results are presented as mean \pm SEM. ** $\mathrm{P}<0.00$ I compared to $\mathrm{pH}$ 7.0.

Low $\mathrm{pH}$ induced artifactual ELISA signals only bind to full length $A \beta$; Authentic anti-A $\beta$ antibodies detect both full length $A \beta$ and $N$ terminal fragments

An epitope mapping study was performed to test if the $A \beta$ domain specificity of the artifactual ELISA signals induced by $\mathrm{pH} 2.5$ exposure differs from the domain specificity of authentic anti-A $\beta$ antibody. ELISA plates were coated with full length sequence human $A \beta 1-42, N$ terminal human $A \beta 1-16$, $C$ terminal human $A \beta 29-40$, and mixture of short human $A \beta$ peptides as indicated on the $x$-axis of Fig 4. Sera from unvaccinated nonTg mice had low anti-A $\beta$ signals with a pH 7 incubation, but an increased signal when incubated at $\mathrm{pH}$ 2.5. This elevation was largely specific for the full length peptide, and the signals found after pH 2.5 for other $A \beta$ peptides or their combinations were no different than the signals seen with PBS (fig. 4A; there is also a small artifactual ELISA signal found against the plate with low $\mathrm{pH}$ incubation). When examining sera from mice vaccinated against $\mathrm{A} \beta$ (thus having authentic anti-A $\beta$ antibodies) the low $\mathrm{pH}$ incubation actually reduced the apparent anti-A $\beta$ titer due to inactivation (process B; fig 3B). Moreover, only ELISA plates containing $A \beta 1-16$ bound the antibodies, consistent with work from our group and others that the predominant epitope for anti-A $\beta$ vaccines is in the $\mathrm{N}$ terminal domain [11]. The epitope specificity of the sera from vaccinated mice was similar to that obtained with a monoclonal anti-A $\beta$ antibody (6E10) directed against the $\mathrm{N}$ terminal domain (Fig $4 c)$, again only associating when $A \beta 1-16$ or $1-42$ was bound to the plate. Thus, the artifactual binding caused by low $\mathrm{pH}$ incubation of normal mouse serum does not bind shorter $A \beta$ peptides, unlike authentic anti-A $\beta$ antibodies.

pH 2.5 incubation induced artifactual anti-A $\beta$ ELISA signal has a lower affinity for $A \beta$ than authentic anti-A $\beta$ antibodies in competition assays

To estimate the affinity of $A \beta$ for the binding found after $\mathrm{pH} 2.5$ dissociation, a competitive inhibition ELISA study was performed. Serum samples were incubated with increasing concentrations of the $\mathrm{A} \beta$ peptide before addition to the ELISA plate. When normal sera from nonTg unvaccinated mice were tested, the increased signal 
A

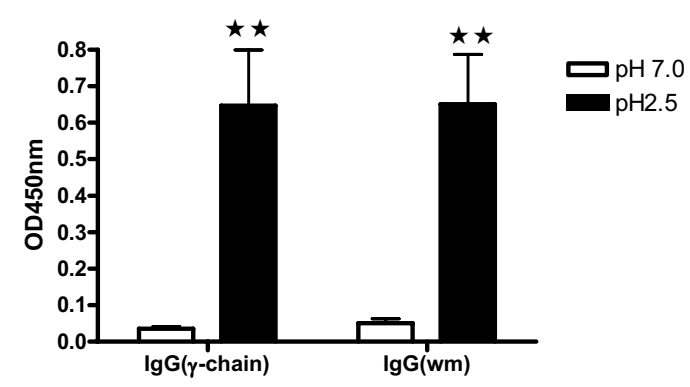

B

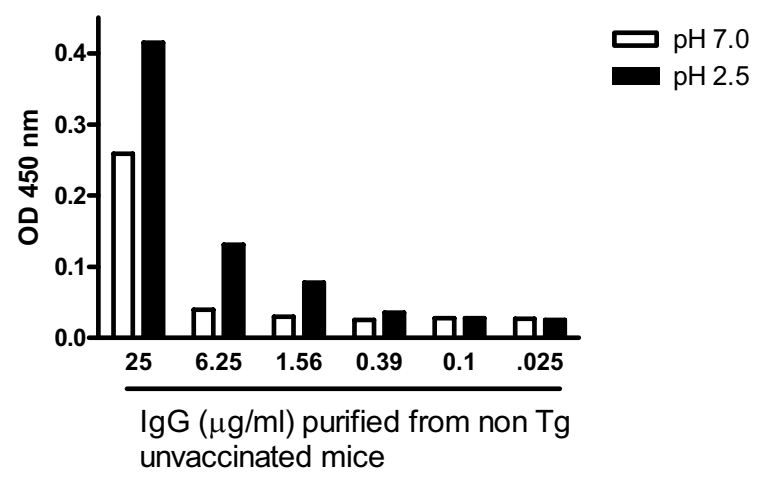

Figure 2

Incubation at $\mathrm{pH} 2.5$ induced artifactual ELISA signal appears to be IgG associated. Panel 2A. Normal sera were collected from non Tg unvaccinated mice, diluted $\mathrm{I}: 400$ and preincubated at either $\mathrm{pH} 7$ (open bars) or $\mathrm{pH} 2.5$ (solid bars) as described in methods. After centrifugation, neutralization and reconstitution of sera volume, the sera were incubated on the ELISA plates coated with human $A \beta I-42$ for 60 minutes. After washing the plate, anti-mouse gamma chain specific (left) or anti-mouse whole IgG (right) were pipetted into the different wells of plate. Panel 2B. Normal sera from nonTg unvaccinated mice were incubated at $\mathrm{pH} 7.0$ (open bars) or $\mathrm{pH} 2.5$ (solid bars) and then IgG was purified with protein A/G (Pierce) as described in methods. Protein was measured with BCA protein assay Kit (Pierce), and dilutions of the purified lgG were incubated as the indicated concentrations on ELISA plates coated with $A \beta I-42$. ELISA assays were completed as described in methods. ** $P<$ 0.001 compared to $\mathrm{pH} 7.0$.

caused by incubation at $\mathrm{pH} 2.5$ was unaffected by competition until $A \beta$ concentrations were at $100 \mu \mathrm{g} / \mathrm{ml}$, and even then the abrogation of signal was incomplete (fig $5 \mathrm{~A})$. In sera from vaccinated nonTg mice, incubation at $\mathrm{pH} 2.5$ reduced the anti-A $\beta$ ELISA signal (due to the inactivation process $B$ ), and this remaining signal was effectively competed at $A \beta 1-42$ concentrations of $1 \mu \mathrm{g} / \mathrm{ml}$ and higher (fig 5B). These data indicated that the authentic anti-A $\beta$ antibodies have at least 100 fold greater affinity for $A \beta$ than the artifactual signal found after incubation at pH 2.5.

\section{Incubation at pH 3.5 avoids both the artifactual ELISA signal and the inactivation of authentic antibody signals caused by incubation at $\mathbf{p H} \mathbf{2 . 5}$}

One possibility is that both the artifactual signal caused by low $\mathrm{pH}$ incubation (process $\mathrm{A}$ ) and the inactivation of authentic anti-A $\beta$ signals (process $B$ ) were due to excessively low $\mathrm{pH}$ during the incubation. Thus, we compared pH 2.5 with a slightly less aggressive incubation at pH 3.5. In normal sera collected from nonTg unvaccinated mice we found that $\mathrm{pH} 2.5$ increased the apparent anti-A $\beta$ ELISA signal, but incubation at pH 3.5 did not (fig 6A). Conversely, when sera from vaccinated nonTg mice were evaluated, incubation at pH 2.5 caused inactivation of the anti-sera raised against human $\mathrm{A} \beta$ 1-42 peptide (figure $5 \mathrm{~B})$, however, incubation at $\mathrm{pH}$ at 3.5 did not result in loss of anti-A $\beta$ signal (fig $6 \mathrm{~B}$ ). Thus, neither process A not process $\mathrm{B}$ is apparent after incubation at $\mathrm{pH} 3.5$

Incubation at $\mathrm{pH} 3.5$ rather than 2.5 can dissociate antigen antibody complexes without causing induction of artifactual signals or denaturing authentic anti-A $\beta$ antibodies

To determine whether low $\mathrm{pH}$ does effectively unmask the anti-A $\beta$ antibodies from $A \beta$ (process $C$ ), we first incubated either a monoclonal antibody (fig 7A) or sera from vaccinated nonTg mice (fig 7B) with 0 or $1 \mu \mathrm{g} / \mathrm{ml} \mathrm{A} \beta$ to form antigen-antibody complexes. We then subjected the samples to incubation at either a) $\mathrm{pH} 7.0$, b) $\mathrm{pH} 2.5$ or c) $\mathrm{pH}$ 3.5 and performed ELISA assays coating the plate with human $A \beta 1-42$. Figure 7. shows that the ELISA signals of both authentic antibodies were dramatically reduced when antigen-antibody complexes were formed by mixing with $1 \mu \mathrm{g} / \mathrm{ml} \mathrm{A} \beta$ and incubated at $\mathrm{pH} 7.0$ (left pair of bars in $7 \mathrm{~A}$ and $7 \mathrm{~B}$ ). Incubation at $\mathrm{pH} 2.5$ (center pair of bars) had two effects; a reduction in signal intensity in the absence of antibody-antigen formation (open bars), and an increase in signal intensity when antigen antibody complexes were formed (solid bars) compared to $\mathrm{pH} 7$ incubation. Importantly changing the low $\mathrm{pH}$ incubation to $\mathrm{pH} 3.5$ avoids both issues. There is no apparent inactivation of antibody at this $\mathrm{pH}$ (compare open bars at $\mathrm{pH} 7$ and $\mathrm{pH} 3.5$ ) and a complete restoration of the ELISA sig- 

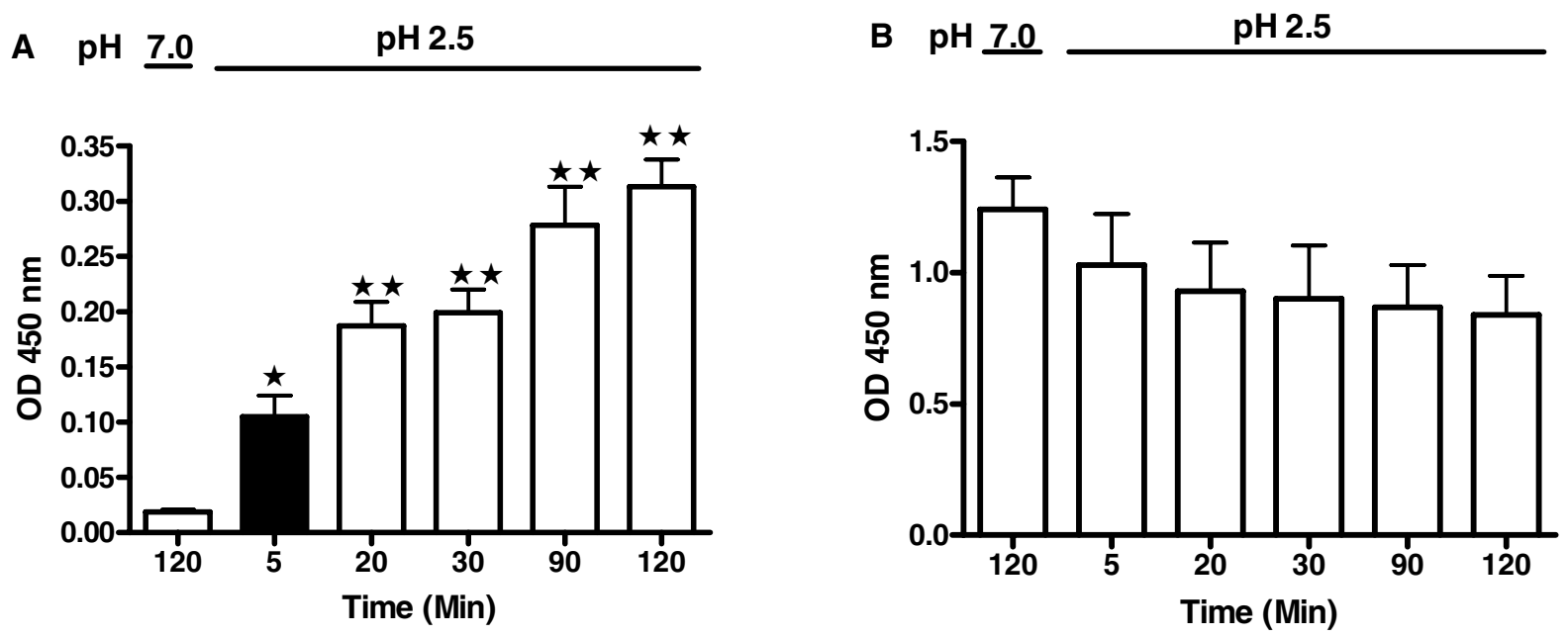

\section{Figure 3}

Duration of $\mathrm{pH} 2.5$ exposure differentially affects ELISA signals in sera from unvaccinated nonTg mice compared to vaccinated nonTg mice. Sera were collected from unvaccinated mice (3A) and mice vaccinated with human $A \beta I-42$ peptide (3B), diluted I:400. Aliquots were incubated with dissociation buffer at $\mathrm{pH} 7$ (open bar, $120 \mathrm{~min}$ ) or $\mathrm{pH} 2.5$ (solid bars) for 5, 20, 30, 90 and 120 minutes. The ELISA assays were completed as described in methods and the optical density at $450 \mathrm{~nm}$ used to estimate the amount of antibody binding to the ELISA plate. Results are presented as mean \pm SEM. $* \mathrm{P}<0.05 ; * * \mathrm{P}<0.00 \mathrm{I}$ compared to $\mathrm{PH}$ 7.0.

nal when antibody-antigen complexes were formed (solid bar equals open bar at pH 3.5. In other work, we have not observed any artifactual increase in ELISA signal when sera from unvaccinated mice are incubated at $\mathrm{pH} 3.5$ (data not shown).

\section{Discussion and conclusion}

Previously, we reported that using a low $\mathrm{pH}$ dissociation procedure in vaccinated APP transgenic mice, anti-A $\beta$ antibody titers increased considerably, consistent with an apparent unmasking of antibody binding sites occluded by bound antigen [5]. Unexpectedly, we subsequently found that this low $\mathrm{pH}$ incubation of normal sera collected from nonTg, unvaccinated mice also showed an similar increase in ELISA signals when human A $\beta 1-42$ was used to coat the ELISA plate. Moreover, this increased signal was not observed to the same extent with other peptides including bovine serum albumin, alpha-synuclein protein, truncated $A \beta 11-20$ and phosphate buffer saline (figure 1B). Our initial interpretation was that the untreated mouse may have anti-A $\beta$ antibodies which were normally occluded in serum by endogenous murine $A \beta$. While this seemed surprising given that there was no reason to expect untreated mice to have either anti-A $\beta$ antibodies, nor sufficient concentrations of circulating $A \beta$ to occlude them, it was consistent with the observations we had up to that time. We also confirmed that the protein in serum that was responsible for the increased ELISA signal after low $\mathrm{pH}$ incubation was IgG by using more selective antibodies as reporters, and demonstrating that the increased $A \beta$ binding was retained when IgG was purified from serum using protein A/G columns (Fig 2). Moreover 

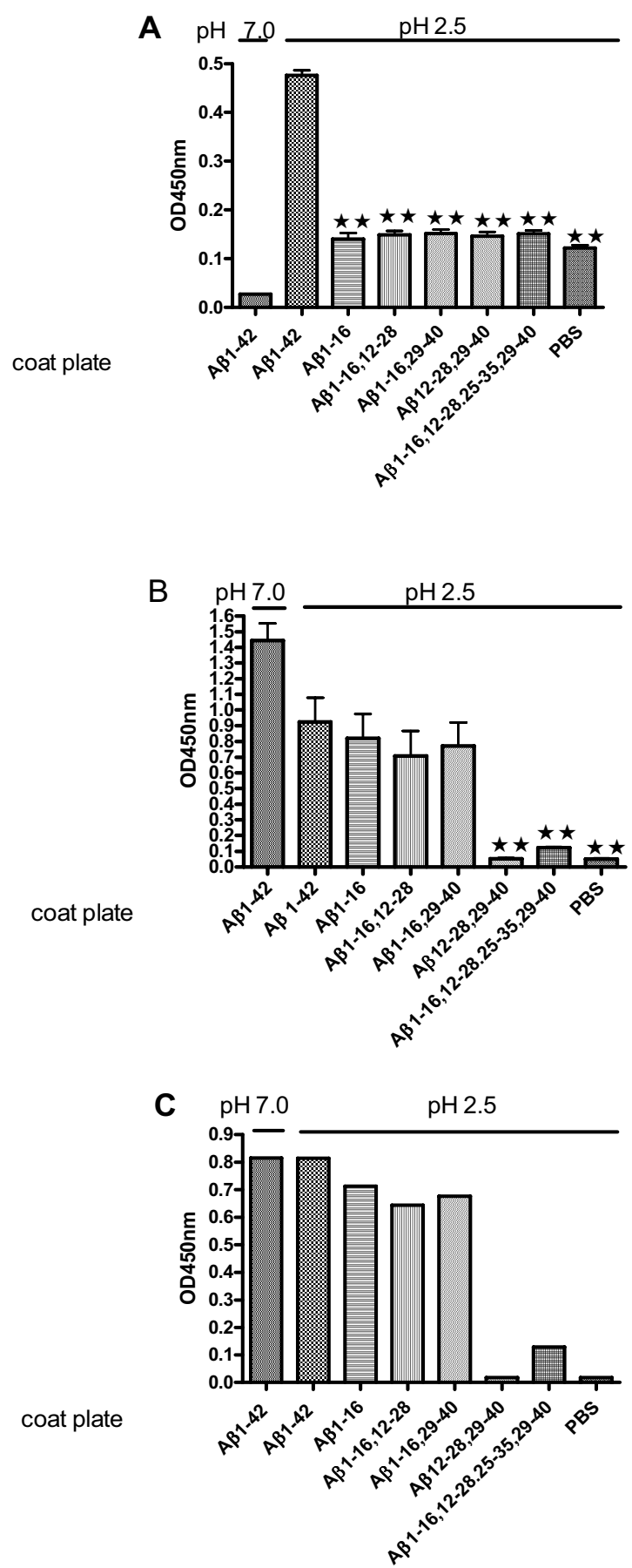

\section{Figure 4}

Incubation at $\mathrm{pH} 2.5$ induced artifactual ELISA signal only interacts with full length $A \beta$; Authentic antibodies bind both full length $A \beta$ and $N$ terminal fragments. Epitope mapping of normal sera from unvaccinated mice (panel $A ; 1: 400$ dilution), mice vaccinated with $A \beta I-42$ peptide (panel $B ; 1: 400$ dilution) or mouse anti-human $A \beta I-I 6$ monoclonal antibody (6EI0; 4C;50 ng/ $\mathrm{ml}$ ) was performed. Full length human $A \beta$ and human $A \beta$ fragments (singly and in combination as indicated on graph) were used to coat the plate and identify the domain that interacted with the $\lg \mathrm{G}$ fractions following $\mathrm{pH} 7$ preincubation (full length $\mathrm{A} \beta$ only) or incubation at $\mathrm{pH} 2.5$ for 20 minutes at RT. After centrifugation and neutralization the samples were then incubated on ELISA plates coated as indicated. Values are mean \pm SEM. $* * \mathrm{P}<0.00 \mathrm{I}$ compared to $\mathrm{pH} 2.5$ plate coated with A $\beta \mathrm{I}-42$ peptide. 
A

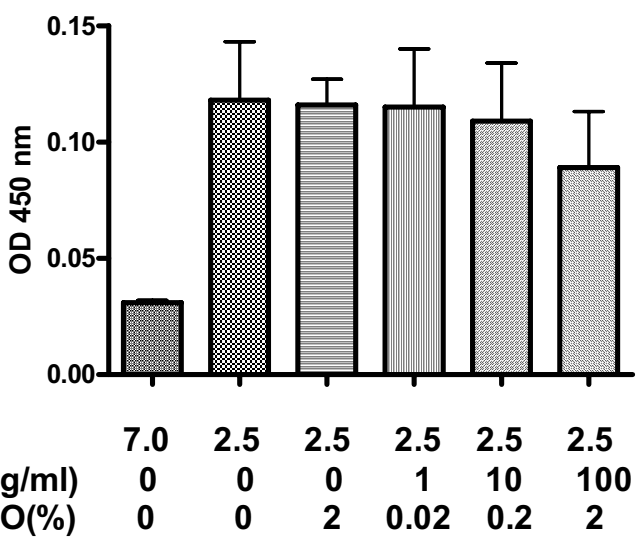

B

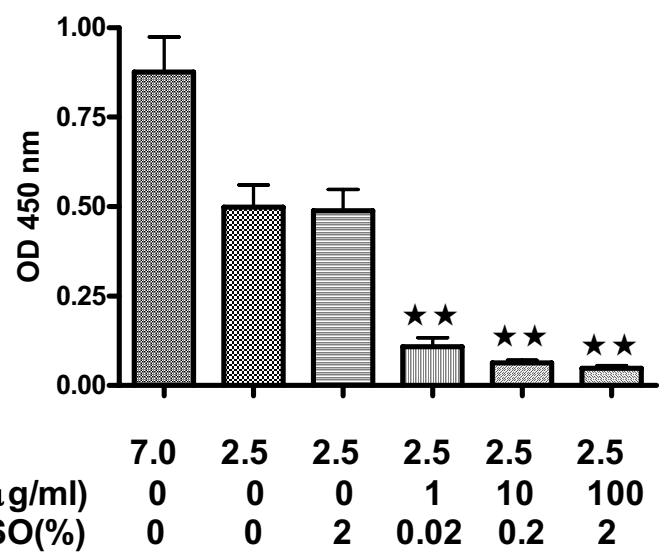

\section{Figure 5}

Incubation at $\mathrm{pH} 2.5$ induced artifactual ELISA signal has a lower affinity for $\mathrm{A} \beta$ than authentic anti-A $\beta$ antibodies in competition assays. Sera from unvaccinated mice (panel $A$ ) or mice vaccinated with $A \beta I-42$ peptide (panel $B$ ), were diluted I: 1000 and preincubated at either $\mathrm{pH} 7$ or $\mathrm{pH}$ 2.5. After centrifugation, neutralization and reconstitution of sera volume, the sera were then incubated with human $A \beta I-42$ peptide, at increasing concentrations at $37^{\circ} \mathrm{C}$ for 60 minutes. Because the $A \beta$ was initially dissolved in DMSO, some samples were also incubated with $2 \%$ DMSO as control. The ELISA assay was then performed as described in methods with no further separation of $A \beta$ and antibody fractions. $* * P<0.00$ I compared to $\mathrm{pH} 2.5$ without $A \beta$ preincubation.

cross reaction between mouse and human $\mathrm{A} \beta$ seemed feasible as Takeshi Kawarabayashi et al [12]showed that BNT-77, a monoclonal antibody against human $A \beta 11-28$ could bind mouse $A \beta$ in nonTg animals.

The interpretation that the increased ELISA signal caused by low $\mathrm{pH}$ incubation was due to endogenous murine anti- $\mathrm{A} \beta$ antibodies was challenged by differences in the behavior of this signal from untreated mice compared to that found after vaccinating nonTg mice against the $A \beta$ peptide to generate authentic anti-A $\beta$ antibodies. First, we observed that unlike the circumstance in transgenic mice, sera from nonTg mice vaccinated against $A \beta$ actually lost apparent ELISA signal against $A \beta$ when incubated at $\mathrm{pH}$ 2.5 (fig 3B). Epitope mapping studies found that the authentic anti-A $\beta$ antibodies produced by vaccination bound $A \beta 1-16$ in largely the same manner as full length $A \beta$, whereas, the acid-induced ELISA signal only could be detected when full length $A \beta$ was bound to the ELISA plate (fig 4). The behavior of a monoclonal murine anti$\mathrm{A} \beta$ antibody (6E10) was quite similar to the immune serum, and not the normal serum. A final inconsistency was the affinity for the $A \beta$ peptide. $A \beta$ at $1 \mu \mathrm{g} / \mathrm{ml}$, the lowest concentration tested, largely eliminated the ELISA signal obtained with sera from vaccinated mice. However, even doses 100 fold greater, had little ability to block the increased ELISA signal found with untreated sera when incubated at $\mathrm{pH} 2.5$.

Thus, whatever is responsible for the increased anti-A $\beta$ ELISA signal found in untreated nonTg mouse serum, it has very low affinity for $A \beta$, and is somehow dependent upon the presence of the entire peptide to exhibit binding behavior. Given the low affinity of $\mathrm{A} \beta$ binding in $\mathrm{pH} 2.5$ treated normal mouse serum, only serum $A \beta$ concentrations that exceeded $100 \mu \mathrm{g} / \mathrm{ml}$ ( $25 \mu \mathrm{M}$ concentration) would be able to mask the antibody. Given that the circulating $A \beta$ concentration in APP overexpressing transgenic mice is 0.5 to $5 \mathrm{nM}$, it would seem this concentration is unlikely ever to occur in nonTg mice. A final argument against this hypothesis is that the nonTg mice vaccinated against $A \beta$ do not appear to have antibody masking. Not only does the low $\mathrm{pH}$ fail to reveal occluded binding sites in the ELISA, there is an apparent time dependent inactivation of these authentic anti- $A \beta$ antibodies caused by the pH 2.5 incubation. Thus we conclude that $\mathrm{pH} 2.5$ incubation causes a low affinity interaction with full length $A \beta$ that is artifactual, and unlikely to represent unmasking of authentic anti $A \beta$ antibodies. We have referred to this as process $\mathrm{A}$ in the results section. 
A

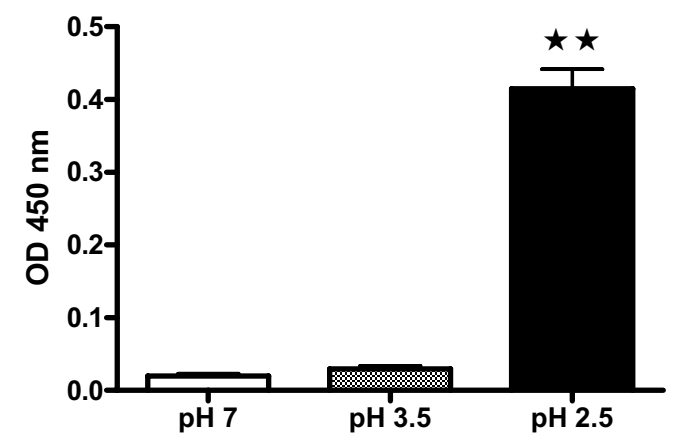

B

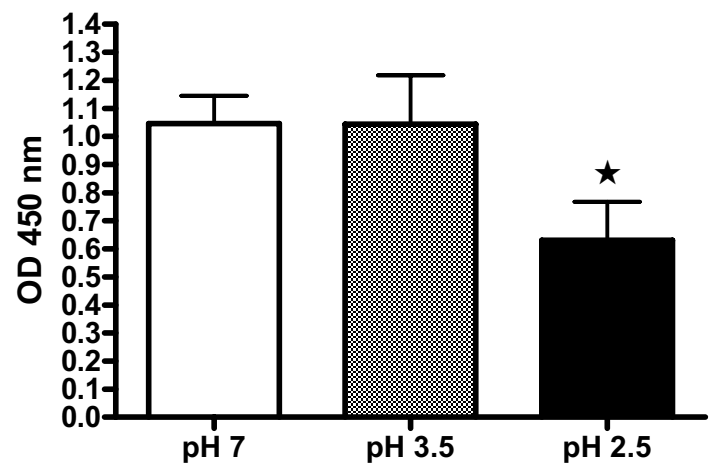

Figure 6

Incubation of sera at $\mathrm{pH} 3.5$ does not induce artifactual ELISA signals nor inactivate authentic anti-A $\beta$ antibody binding in ELISA assay. Sera collected from unvaccinated mice (6A) and mice vaccinated with $A \beta I-42$ peptide (6B) were incubated with dissociation buffer at $\mathrm{pH} 7.0$ (open bars), 3.5 (grid bars) or 2.5 (solid bars) for 20 minutes, separated by centrifugation through 10,000 MW filters neutralized and reconstituted to original volume. They were then incubated in a standard ELISA assay using full length $\mathrm{A} \beta$ to coat the plate. $* \mathrm{P}<0.05$ compared to $\mathrm{pH} 7.0$; $* * \mathrm{P}<0.00 \mathrm{I}$ compared to $\mathrm{pH}$ 7.0.

One possibility is the IgG responsible for the apparent anti-A $\beta$ ELISA signal enhanced by low $\mathrm{pH}$ are natural polyreactive autoantibodies $[13,14]$ which recognize several structurally unrelated epitopes, or relatively nonselec- tive antibodies that recognize $A \beta$ and a large number of similar peptide sequences with low affinity. These may be occluded by antigens other than $\mathrm{A} \beta$, and become available for binding in the ELISA assays due to unmasking. How-
A

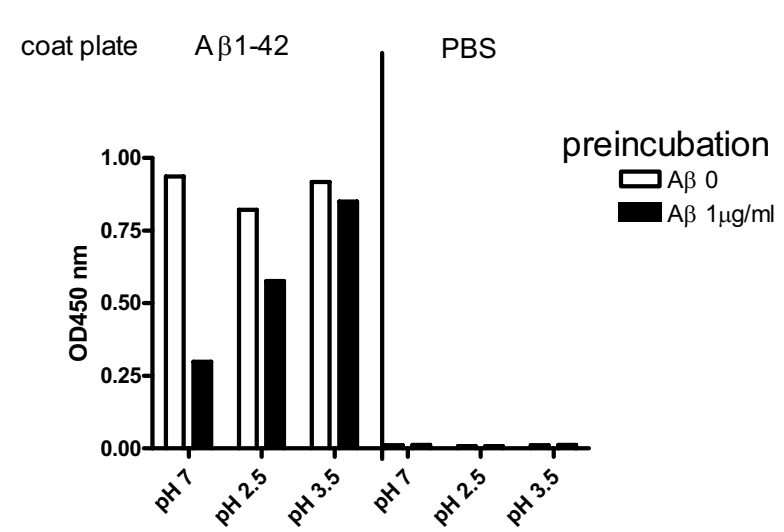

B

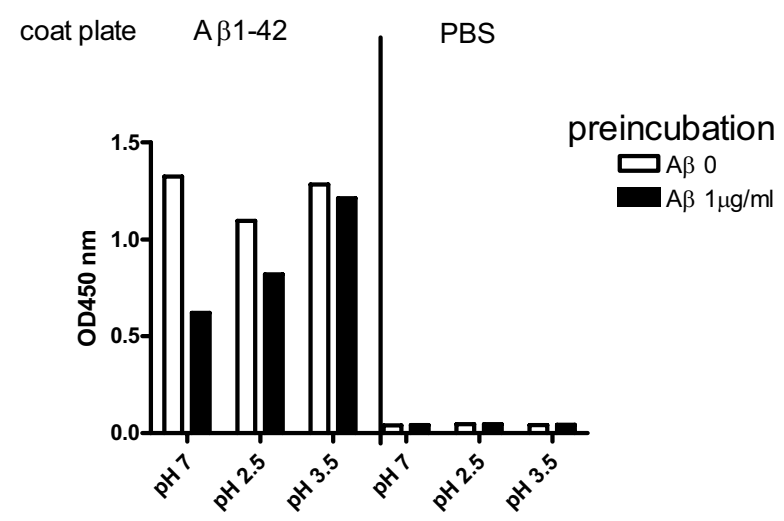

Figure 7

Dissociation of $A \beta-\lg G$ immune complexes occurs at both $\mathrm{pH} 2.5$ and $\mathrm{pH}$ 3.5. Mouse anti-human $\mathrm{A} \beta|-| 6$ monoclonal antibody $(6 \mathrm{EI})$ at $10 \mu \mathrm{g} / \mathrm{ml}(7 \mathrm{~A})$ and serum from mice vaccinated with $\mathrm{A} \beta$ diluted $\mathrm{I}: 100$ were preincubated with $\mathrm{A} \beta \mathrm{I}-42$ peptide at I $\mu \mathrm{g} / \mathrm{ml}$ to form antigen-antibody complexes (solid bars) or preincubated with PBS as a control (open bars) at $37^{\circ} \mathrm{C}$ for 60 minutes. Aliquots from each sample were then incubated with a I0-fold larger volume (I:1000 final serum dilution in panel B) of dissociation buffer at pH 7, pH 2.5 and pH 3.5, respectively, for 20 minutes, separated by centrifugation through $10,000 \mathrm{MW}$ filters, neutralized and reconstituted to original volume for standard ELISA assay with full length human $A \beta$ coating the plate. 
ever, our most favored interpretation is that the low $\mathrm{pH}$ partially denatures the antibodies, revealing hydrophobic residues typically shielded from interaction by their internalized location. These residues may then interact with other hydrophobic domains, such as found on the full length $A \beta$ peptide, with low affinity but high capacity, since many IgG molecules may be susceptible to this denaturation. Such denaturation may similarly account for the loss of authentic anti-A $\beta$ activity caused by low $\mathrm{pH}$ treatment of sera from vaccinated mice, the inactivation response we referred to as process $\mathrm{B}$ in the results.

Fortunately, the use of a less stringent method of dissociating antigen-antibody complexes can unmask occluded antibodies without a) artifactually increasing anti-A $\beta$ ELISA signal or b) inactivating authentic anti-A $\beta$ antibodies. Incubating at $\mathrm{pH} 3.5$ instead of $\mathrm{pH} 2.5$ largely eliminates the problems reported here in the acid dissociation procedure (fig 6). After spiking a serum sample with $\mathrm{A} \beta$ and preincubating to form antigen-antibody complexes, we observed significant loss of ELISA signal when sera were subsequently treated in a normal manner at neutral $\mathrm{pH}$. However, incubating spiked sera at $\mathrm{pH} 3.5$ restored the ELISA titer values to those found in the absence of added exogenous $A \beta$ peptide (fig 7).

In our prior work (5), we now believe these three phenomena were occurring simultaneously to produce the data we observed. All of this prior work used APP transgenic mice, which would be expected to have high concentrations of circulating $\mathrm{A} \beta$ to bind to anti-A $\beta$ antibodies (most of the work reported here used nonTg mice). We suspect that in addition to unmasking (process $\mathrm{C}$ ) there were counteracting influences of authentic antibody inactivation (process B) and artifactual increases in ELISA signals (process A). in the initial work, although all three processes were active, the unmasking dominated when evaluating vaccinated APP transgenic mice that had high levels of both authentic antibodies and high levels of circulating A $\beta$. Only when we examined normal serum from unvaccinated nonTg mice did we reveal process A (an artifact) and only when we examined serum from vaccinated transgenic mice did we observe inactivation (process $\mathrm{B}$ ). While we are confident that antibody masking was occurring in our earlier work and the data are accurate, our own subsequent work and reports from our colleagues indicated that $\mathrm{pH} 2.5$ incubations were doing more than simply dissociating antigen-antibody complexes. Therefore we feel it important to report his improvement to our earlier technique so that others do not suffer through the same trials we have in understanding the complexities involved.

In conclusion, dissociation of antigen-antibody complexes is an important step in evaluating the anti-A $\beta$ anti- body titers in serum from APP transgenic mice, and most likely in human sera as well. This is most significant when the anti-A $\beta$ antibody titers are low, as high titers result in excess antibody relative to $\mathrm{A} \beta$ peptide. Incubations at $\mathrm{pH}$ 2.5 cause both spurious increases in ELISA signals that are not due to high affinity anti-A $\beta$ antibodies, and partially inactivate the ELISA signals resulting from authentic high affinity anti-A $\beta$ antibodies probably due to denaturation. While both artifactual signals and antibody inactivation are absent at $\mathrm{pH} 3.5$, antigen-antibody unmasking still occurs. This improved assay should be valuable in accurately assessing anti-A $\beta$ antibody titers in transgenic mice and in humans treated with immunotherapy.

\section{Methods \\ Vaccination protocols}

The Tg2576 APP transgenic mice [15] and nonTg littermates were produced as described previously and have been bred continuously for over 10 years in our colony [16]. NonTg mice from this breeding were vaccinated with human A $\beta 1-42$ peptide (American peptide) as described previously [2]. Briefly, A $\beta$ Peptide was suspended in pyrogen-free Type I water at $2.2 \mathrm{mg} / \mathrm{ml}$ then mixed with $10 \times$ PBS to yield $1 \times$ PBS solution and incubated overnight at $37^{\circ} \mathrm{C}$. The following day, two volumes of $1 \times$ PBS was added to dilute the $A \beta$ peptide further, and then the peptide suspension was emulsified with an equal volume of Freund's complete adjuvant (Sigma). The vaccine preparation $(100 \mu \mathrm{g} \mathrm{A} \beta / 300 \mu \mathrm{l}$ volume) was injected into each mouse subcutaneously. For the second immunization, the same materials were prepared freshly in incomplete Freund's adjuvant (Sigma) at 14 days after first injection. The third and fourth boosts were made incomplete Freund's at monthly intervals after the second immunization. Mice were vaccinated beginning at 9 months of age and sacrificed at 12 months of age, 14 days after the fourth inoculation.

\section{Dissociation of anti-A $\beta$ antibody from $A \beta$ in serum}

Sera were diluted 1:100 with dissociation buffer (PBS buffer with 1.5\% BSA and $0.2 \mathrm{M}$ glycine-acetate), $\mathrm{pH} 2.5$ and/or pH 3.5 to a 500 ul final volume and incubated for $20 \mathrm{~min}$. at room temperature (RT). The sera were then pipetted into the sample reservoir of Microcon centrifugal filter device, YM-10 (10,000 MW cut-off; Millipore) and centrifuged at $8,000 \times \mathrm{g}$ for $20 \mathrm{~min}$. at RT. The sample reservoir was then separated from the flow through, placed inverted into a second tube and centrifuged at $1000 \times \mathrm{g}$ for $3 \mathrm{~min}$. at RT. The collected solution containing the antibody dissociated from the $\mathrm{A} \beta$ peptide was adjusted to $\mathrm{pH}$ 7.0 with $1 \mathrm{M}$ Tris buffer, $\mathrm{pH} 9.0$. The retentate volume was reconstituted to the initial volume $(500 \mu \mathrm{l})$ with ELISA dilution buffer (PBS with $1.5 \%$ BSA and $0.1 \%$ Tween-20). The collected sera were then added to an ELISA plate at several dilutions to determine the antibody titer. As con- 
trol, the same serum was treated with identical process except using dissociation buffer, $\mathrm{pH} 7.0$ instead of dissociation buffer, $\mathrm{pH} 2.5$.

\section{Purification of IgG from mouse sera}

The sera were pooled from four nonTg unvaccinated mice, $500 \mu \mathrm{l}$ was added to $2 \mathrm{ml}$ dissociated buffer at $\mathrm{pH} 2.5$ or pH 7.0 respectively, incubated 20 minutes at room temperature then neutralized with $1 \mathrm{M}$ Tri/HCL pH9.0 (pH 2.5 samples). The samples were mixed with an equal volume binding buffer (provided by ImmunoPure (A/G) IgG purification Kit, PIERCE 44902, Rockford IL USA) and then IgG were collected according to the instructions. Briefly, the diluted samples were applied to the Protein A/ G Columns. After washing the Protein A/G columns with binding buffer, the IgG captured by the Protein A/G Columns were eluted by elution buffer followed by collection of successive $1 \mathrm{ml}$ fractions. The eluted fractions were immediately adjusted to physiologic $\mathrm{pH}$ by adding $100 \mu \mathrm{l}$ of $1 \mathrm{M}$ Tris $\mathrm{pH} 9.0$ to $1 \mathrm{ml}$ of eluate and then the procedure for buffer exchange (desalting) was applied with 5 ml D-salt Dextran Desalting Columns. The purified IgG were measured by BCA Protein Assay Kit (PIERCE 23227).

\section{Measurements of antibody titers by ELISA}

Ninety-six-well Immulon 4HBX plates (Dynex) were coated with $50 \mu \mathrm{l}$ per well of human $\mathrm{A} \beta 1-42$ peptide $5 \mu \mathrm{g} /$ $\mathrm{ml}$ in PBS buffer, $\mathrm{pH} 7.0$ and incubated overnight at $4{ }^{\circ} \mathrm{C}$. The plates were washed five times with $0.45 \%$ $\mathrm{NaCl}+0.05 \%$ Tween-20 (washing buffer, WB) and blocked at $37^{\circ} \mathrm{C}$ for 1 hour with blocking buffer $(1.5 \%$ BSA and $0.05 \%$ Tween-20 in PBS). After five washes with $\mathrm{WB}$, the sera were added to the plates in duplicate and incubated for 1 hour at $37^{\circ} \mathrm{C}$. The plates were washed 10 times and anti-mouse IgG conjugated with horseradish peroxidase (HRP) (Sigma Chemical Co. St. Louis, MO) diluted 1:5000 was added to the plates and incubated for 1 hour at $37^{\circ} \mathrm{C}$. The plates were then washed ten times and developed with $\left(3^{\prime}, 3^{\prime}, 5^{\prime}, 5^{\prime}\right.$-Tetramethylbenzidine) TMB (Sigma). The reaction was stopped with $2 \mathrm{M}$ sulphuric acid. The plates were analyzed spectrophotometrically at $450 \mathrm{~nm}$.

\section{Statistical analysis}

Data were analyzed by one-way analyses of variance (ANOVA), followed by Fisher's least significance difference means comparisons using StatView (SAS institute).

\section{Abbreviations}

AD: Alzheimer's Disease

APP: Amyloid Precursor Protein

BSA; bovine serum albumin
ELISA: Enzyme linked immunosorbent assay

nonTg; nontransgenic

PBS; phosphate buffered saline

\section{Authors' contributions}

Q-Y L prepared the vaccines and injected the mice, performed the ELISA assays and collected and analyzed the results as well as drafted the first version of the manuscript. MG generated the mice for the study, prepared the vaccines, collected the samples used for the ELISA procedures and assisted in editing the manuscript. KU and CC directed the ELISA procedures and assisted in data analysis. DM conceived the design of the study, guided data interpretation and played the major role in revision of the manuscript. All authors read and approved the final manuscript.

\section{Acknowledgements}

This work was supported by NIH grants AG 18478 and AG 25509 to D M.

\section{References}

I. Schenk D, Barbour R, Dunn W, Gordon G, Grajeda H, Guido T, Hu K, Huang J, Johnson-Wood K, Khan K, Kholodenko D, Lee M, Liao Z, Lieberburg I, Motter R, Mutter L, Soriano F, Shopp G, Vasquez N, Vandevert C, Walker S, Wogulis M, Yednock T, Games D, Seubert P: Immunization with amyloid-beta attenuates Alzheimer-disease-like pathology in the PDAPP mouse. Nature 1999, 400: $173-177$.

2. Morgan D, Diamond DM, Gottschall PE, Ugen KE, Dickey C, Hardy J, Duff K, Jantzen P, DiCarlo G, Wilcock D, Connor K, Hatcher J, Hope C, Gordon M, Arendash GW: A beta peptide vaccination prevents memory loss in an animal model of Alzheimer's disease. Nature 2000, 408:982-985.

3. Janus C, Pearson J, McLaurin J, Mathews PM, Jiang Y, Schmidt SD, Chishti MA, Horne P, Heslin D, French J, Mount HT, Nixon RA, Mercken M, Bergeron C, Fraser PE, George-Hyslop P, Westaway D: A beta peptide immunization reduces behavioural impairment and plaques in a model of Alzheimer's disease. Nature 2000, 408:979-982.

4. Wilcock DM, Gordon MN, Ugen KE, Gottschall PE, DiCarlo G, Dickey C, Boyett KW, Jantzen PT, Connor KE, Melachrino J, Hardy J, Morgan D: Number of Abeta inoculations in APP+PSI transgenic mice influences antibody titers, microglial activation, and congophilic plaque levels. DNA Cell Biol 200I, 20:73I-736.

5. Li QY, Cao CH, Chackerian B, Schiller J, Gordon M, Ugen KE, Morgan $\mathrm{D}$ : Overcoming antigen masking of anti-amyloidbeta antibodies reveals breaking of $B$ cell tolerance by virus-like particles in amyloidbeta immunized amyloid precursor protein transgenic mice. BMC Neurosci 2004, 5:21.

6. Monsonego A, Maron R, Zota V, Selkoe DJ, Weiner HL: Immune hyporesponsiveness to amyloid $\beta$-peptide in amyloid precursor protein transgenic mice: Implications for the pathogenesis and treatment of Alzheimer's disease. Proc Natl Acad Sci USA 2001, 98:19273-19278.

7. Weksler ME, Relkin N, Turkenich R, LaRusse S, Zhou L, Szabo P: Patients with Alzheimer disease have lower levels of serum anti-amyloid peptide antibodies than healthy elderly individuals. Exp Gerontol 2002, 37:943-948.

8. DU Y, Dodel R, Hampel H, Buerger K, Lin S, Eastwood B, Bales K, Gao F, Moeller HJ, Oertel W, Farlow M, Paul S: Reduced levelsof amyloid $\beta$-peptide antibody in Alzheimer disease. Neurology 200I, 57:80I-805.

9. Hyman BT, Smith C, Buldyrev I, Whelan C, Brown H, Tang MX, Mayeux R: Autoantibodies to amyloid-beta and Alzheimer's disease. Ann Neurol 200I, 49:808-10. 
10. Mruthinti S, Buccafusco J], Hill WD, Waller JL, Jackson TW, Zamrini EY, Schade RF: Autoimmunity in Alzheimer's disease: increased levels of circulating IgGs binding A $\beta$ and RAGE peptides. Neurobiology of Aging 2004, 25: 1023-10323.

II. Dickey CA, Morgan DG, Kudchodkar S, Weiner DB, Bai Y, Cao C, Gorden MN, Ugen KE: Duration and specificity of humoral immune responses in mice vaccinated with the Alzheimer's disease-associated beta-amyloid I-42 peptide. DNA Cell Biol 200I, 20:723-729.

12. Kawarabayashi K, Younkin LH, Saido TC, Shoji M, Ashe KH, Younkin SG: Age-dependent changes in brain, CSF, and plasma amyloid $\beta$ protein in the Tg2576 transgenic mouse model of Alzheimer's disease. J Neurol Sci 200I, 2 I:372-38I.

13. Valentin FB, Rabilloud R, Rousset B: Evidence for anti-tubulin autoantibodies in the form of immune complexes in human sera Clin. Exp Immunol 1988, 71:26I-268.

14. Bouvet JP, stahi D, Rose S, Quan CP, Kazatchkine MD, Kaveri SV: Induction of natural autoantibody activity following treatment of human immunoglobulin with dissociating agents. J Autoimmunity 200I, 16:163-172.

15. Hsiao K, Chapman P, Nilsen S, Eckman C, Harigaya Y, Younkin S, Yang F, Cole G: Correlative memory deficits, Abeta elevation, and amyloid plaques in transgenic mice. Science 1996, 274:99-102.

16. Holcomb L, Gordon MN, McGowan E, Yu X, Benkovic S, Jantzen P, Wright K, Saad I, Mueller R, Morgan D, Sanders S, Zehr C, O'Campo K, Hardy J, Prada CM, Eckman C, Younkin S, Hsiao K, Duff K: Accelerated Alzheimer-type phenotype in transgenic mice carrying both mutant amyloid precursor protein and presenilin transgenes. Nat Med 1998, 4:97-100.

\section{Publish with Bio Med Central and every scientist can read your work free of charge}

"BioMed Central will be the most significant development for disseminating the results of biomedical research in our lifetime. "

Sir Paul Nurse, Cancer Research UK

Your research papers will be:

- available free of charge to the entire biomedical community

- peer reviewed and published immediately upon acceptance

- cited in PubMed and archived on PubMed Central

- yours - you keep the copyright 